\section{NTT to unhook mobile phones}

Tokyo. One of the world's biggest companies, Nippon Telegraph and Telephone Corporation (NTT), is preparing to spin off one of its most promising and most researchintensive businesses.

On 1 July, under a government policy aimed at promoting fairer competition in Japan's telecommunications industry, the rapidly growing mobile communications sector of NTT will become a new company, taking with it a sizeable and valuable section of NTT's army of researchers. But observers question whether NTT intends to divest itself fully of this part of its business and research enterprise.

NTT employs about a quarter of a million people and has an annual operating income of nearly $¥ 6.5$ million million (US\$50,000 million). The company has more than 3,000 researchers in four centres and two laboratories doing fundamental work in such areas as optics, semiconductors, superconductivity and nanotechnology.

The success of the company is built on its monopoly of most of Japan's domestic telecommunications networks. In 1985, the Japanese telecommunications industry was privatized and several new companies entered the domestic market. But those companies have only a tiny market share because NTT still controls most of the telecommunications infrastructure.

In 1990 , an advisory committee to the Ministry of Posts and Telecommunications recommended that NTT be split into regional companies, as occurred in the United States with AT\&T, to promote fairer competition. But the recommendations were strongly resisted by NTT, some powerful leaders of Japanese industry and the Ministry of Finance, which has been making money by periodically selling off NTT shares to the public. In the end, it was agreed that only the mobile communications sector of NTT would be divested and that no further steps would be taken until at least 1996 (see Nature 344, 480; 1990).

Nevertheless, the loss of the mobile telecommunications sector would represent a very significant divestiture for NTT. Mobile communications companies are the "growth hounds" of the telecommunications industry, says David Hytha, managing director of Network Wireless Systems at AT\&T Japan Ltd, as the use of automobile, portable and cordless telephones has soared in Japan and elsewhere in the developed world.

In the mid-1980s, Hytha says, few people in the telecommunications industry paid attention to wireless technology. Instead, all eyes were focused on high-speed digital cable networks and fibre optics. But now, he says, "everybody wants to go wireless". As a result, radio engineers and researchers on analog systems who were once considered to be on the fringe have "suddenly moved to centre stage".

Japan trails the United States in research on mobile communications, Hytha says. It is especially deficient in radio engineers, mathematicians and software engineers capable of writing the rapidly evolving software and algorithms needed for mobile communications. The situation is made even more complicated by the existence of different standards for mobile communications in Japan, Europe and the United States.

The new company, to be called NTT Mobile Communications Network Inc., will take with it 250 mobile communication researchers from NTT. Or at least that is how it appears on paper. In fact, the researchers will not actually go anywhere. All of them will continue working at existing NTT research centres, 160 at NTT's Yokosuka research centre south of Tokyo and most of the rest at the Musashino research centre on the western outskirts of Tokyo.

NTT officials insist that the research and development arms of the two companies will be distinct. The researchers will be on different floors, says Shuichi Shindo, executive manager of the research and development department of NTT's mobile communications sector, and there will be no overlap in research between the two companies. An NTT spokesman says that the new company will be charged "at market rates" for access to NTT research and development.

But the division of research and development will not be clear-cut. Much basic research and development with applications in mobile communications, for example the development of integrated circuits, will be carried out at NTT's research laboratories. And some mobile communications researchers will stay at NTT, although they will not work on the development of portable telephone systems, cordless telephones or pagers and the technologies assigned to the new company.

Many observers question whether NTT intends to leave the field entirely. There are many emerging technologies that go beyond portable telephones, cordless telephones and pagers. A personal handy telephone, a cordless telephone that can be used outdoors, is expected on the market soon, and NTT may find it hard to turn its back on the potential of such technologies as wireless portable computers and wireless local area networks.

One thing is clear. NTT's departure from mobile communications will be very gradual. The new company will be owned totally by NTT, and, although NTT says it plans to follow government policy and reduce its holdings, shares in the new company will not be listed on the stock exchange until 1997.

David Swinbanks
IN BRIEF

London. Next month an international research institute will open at the University of Cambridge to strengthen collaboration between British mathematicians and their colleagues around the world. The Isaac Newton Institute for Mathematical Sciences is modelled on two centres in the United States - the Institute of Theoretical Physics in Santa Barbara and the Mathematical Sciences Research Institute in Berkeley, both part of the University of California.

The Newton institute will run four sixmonth research programmes a year in various cross-disciplinary subjects. The first batch will cover low-dimensional topology and quantum field theory, astrophysical dynamo theory, L-functions and arithmetic and the modelling of epidemics.

The impetus for the institute, according to its deputy director, Peter Goddard, came from a feeling that Britain was missing out on a good deal of international scientific activity. $\mathrm{He}$ and his colleagues could take part in cross-

disciplinary projects in other countries, but were unable to host similar events.

Apparently they were right, for some 75 per cent of those who responded to a call for the initial programmes live outside Britain. Researchers will work at the institute for periods of between two weeks and the entire six months of a project.

I.M.

London. British staff at the Joint European Torus (JET), an experimental nuclear fusion project, staged the second of a series of one-day strikes yesterday (17 June) in support of a long-running campaign for parity of pay with their European colleagues. This follows the success of the first strike last Friday, which involved 112 British scientists and technicians and featured pickets outside the Culham Laboratory in Oxfordshire, where the project is based. A handful of European scientists joined the first strike. A ballot of union staff (see Nature $\mathbf{3 5 7}$. $270 ; 1992$ ) showed 80 per cent support for action up to and including strikes.

Union representatives have had no response from JET's management to their complaints over pay or their concerns about what will happen to them after the JET project ends in 1996. Further strikes will be planned on a week-by-week basis.

I.M.

Munich. A three-day festival of science held last weekend in towns all over France attracted an estimated four million people. The 1,500 events ranged from sciencefiction films to the Paris 'Market for the Year 2000' with its exhibition of future cars and cheese-making machines. The Ministry of Science and Space organized this first-ever national celebration of science and asked all French laboratories to open their doors to the public. 